\title{
MICROBIOLOGICAL QUALITY OF MINIMALLY PROCESSED VEGETABLES SOLD IN PORTO ALEGRE, BRAZIL
}

\author{
Silvia R. Pavan da Silva; Sylvia E. Frizzo Verdin; Dariane C. Pereira; Aline M. Schatkoski; Marilise B. Rott; \\ Gertrudes Corção*
}

Departamento de Microbiologia, Instituto de Ciências Básicas da Saúde, Universidade Federal do Rio Grande do Sul, Porto Alegre, RS, Brasil

Submitted: November 09, 2006; Returned to authors for corrections: July 16, 2007; Approved: November 19, 2007.

\begin{abstract}
Minimally processed vegetables go through various steps during their preparation, with many modifications to their natural structure. However, they must maintain the same quality as the fresh produce. The aim of the present study was to quantify mesophilic and psychrotrophic microorganisms and total and faecal coliforms, and to assess the presence of Escherichia coli, parasites, and dirt material in ready-to-eat minimally processed vegetables. Fifty-six samples of minimally processed vegetables were analysed for the presence of mesophilic and psychrotrophic microorganisms by the plate-count method. Monthly means ranged from $4.7 \times 10^{5}$ to $1.6 \times 10^{8} \mathrm{CFU} / \mathrm{g}$ and from $7.9 \times 10^{6}$ to $2.7 \times 10^{8} \mathrm{CFU} / \mathrm{g}$, respectively for mesophilic and psychrotrophic microorganisms. Coliforms were analysed by the multiple-tube method; total coliforms ranged from $<3$ to $\geq$ $2.4 \times 10^{4} \mathrm{MPN} / \mathrm{g}$ and faecal coliforms from $<3$ to $1.1 \times 10^{4} \mathrm{MPN} / \mathrm{g}$. Escherichia coli was detected in eight samples. Out of 52 samples, eight (15.3\%) contained oocysts of Eimeria spp.. Dirt matter, such as insect body parts and young mites, was also found. Contamination of faecal origin was observed in these samples, suggesting that either the sanitisation of the product was unsuccessful, or soil or irrigation water could be the source of these microorganisms.
\end{abstract}

Key words: minimally processed vegetables, microbiologic quality, and parasitological analysis

\section{INTRODUCTION}

Fresh fruit and vegetables are an important source of nourishment and a vital ingredient in healthy and balanced diets. Fresh produce is highly recommended in any diet, virtually without quantitative restriction. Minimally processed vegetables are typically defined as a product that undergoes some industrial processing and should maintain its original characteristics (18). Washing and soaking with sanitising chemicals, followed by slicing, are stages of a complex, multipart process developed to preserve and guarantee the quality of minimally processed vegetables. Packaging in modified atmospheres, together with refrigeration, slows down air flow and consequently the respiration of the vegetables. Bacterial growth is also inhibited, and the shelf-life of the product is enhanced (6).
Advances in processing and conservation technologies, together with better distribution and trading, have made nearly all kinds of fresh fruits and vegetables available, with good quality. On the other hand, some of the technologies employed have increased health hazards, mainly associated with pathogenic microorganisms (2). Several outbreaks of gastroenteritis have been imputed to the consumption of contaminated fresh vegetables. Toxinfections associated with ingestion of vegetables, which revealed a lack of hygiene during manipulation, have been recorded $(11,16)$.

Food-borne parasites have received little attention in developing countries (6). As a rule, these organisms infest vegetables while still in the field, and are usually transmitted by contaminated wash water and spread by ineffective hygiene practices (2). Control of protozoans and helminths is a constant

*Corresponding Author. Mailing address: Rua Sarmento Leite, n 500 sala 158 ICBS - UFRGS. Bairro Cidade Baixa, Porto Alegre, RS, Brasil. Tel.: +55513308-4111 Fax: +5551 3308-3445. E-mail: corcao@ufrgs.br 
object of public-health strategies, especially where reclaimed water is used. The resistant cysts or eggs of these organisms enhance their survival in the natural environment (4).

Food safety in ready-to-eat products, especially raw foods, has long been an object of study. In order to effectively assess all the steps in a minimal-processing plant and to analyse the entire food-production chain, it is important to identify the origin of the likely contaminants. A number of studies have assessed the microbiologic conditions of ready-to-eat vegetables available in supermarkets, street markets, and grocery shops, as well as in self-service and fast-food restaurants $(10,19)$. In light of the commercial importance of these food items, including minimally processed raw vegetables, the present study aimed to determine the degree of bacteriologic and parasitologic contamination in minimally processed, ready-to-eat vegetables available in supermarkets in the city of Porto Alegre (Brazil) and to contribute to knowledge of the microbiologic quality of these products.

\section{MATERIALS AND METHODS}

\section{Sample collection}

Ready-to-eat vegetables were sampled monthly in supermarkets in Porto Alegre, Brazil, from July 2004 to August 2005. The purchased products were in individual, semipermeable packaging, in modified atmosphere, and kept under constant refrigeration. Immediately upon purchase, samples were transported at $10^{\circ} \mathrm{C}$ to the laboratory for analysis.

\section{Sample preparation}

Each sample was composed of three vegetable packets from the same lot number. Each sample provided $25 \mathrm{~g}$ of vegetable material, which was homogenised in $225 \mathrm{~mL} 0.1 \%$ peptone water. This suspension was serially diluted in $0.1 \%$ peptone water. For the parasitologic analysis, $200 \mathrm{~g}$ of sample was used. For analysis of dirt content, $100 \mathrm{~g}$ was used.

\section{Microbiological analysis}

For the total counts of mesophilic and psychrotrophic microorganisms, the serial dilutions were seeded onto Plate Count Agar (PCA). The plates were incubated at $35^{\circ} \mathrm{C}$ for $24-48$ hours and at $10^{\circ} \mathrm{C}$ for up to 7 days, for the mesophilic and psychrotrophic counts, respectively. For the counts of total coliforms, faecal coliforms, and Escherichia coli, samples were analysed and the results interpreted following the multiple-tube fermentation technique (20). All analyses were carried out in duplicate.

\section{Parasitological analysis}

Vegetable leaves were washed in a rectangular plastic container, and then sorted and individually brushed with a $0.5 \%$ neutral detergent solution. The wash-out fluid was strained through a conical sedimentation chalice lined with gauze. The plastic container was washed twice with $10 \mathrm{~mL}$ of the same detergent solution, and this liquid was collected in the same flask as the wash-outs (15). The liquid phase was left to rest for $24 \mathrm{~h}$. Afterwards, approximately 2 drops of the sediment were examined, in duplicate, by means of an optical microscope (100x and 400x), according to Lutz (8). Next, the sediments obtained as above were transferred to a $30-\mathrm{mL}$ centrifuge tube, and the supernatant was discarded. Faust's centrifuge-flotation method (5) was used to observe cysts and oocysts by means of an optical microscope (100x and 400x ).

\section{Analysis of dirt matter by filtration}

One hundred grammes of each original sample was homogenised in a large flask containing $400 \mathrm{~mL}$ distilled water. The solution obtained was filtered through a Büchner funnel with filter paper, which was then removed and examined under a stereomicroscope to investigate the presence of dirt matter. Any dirt matter detected was quantitatively enumerated, and ranked in one of three levels: Level $1=$ rare, with 0 to 3 flecks of dirt matter; level $2=$ moderate, with between 3 and 5 flecks of dirt matter; and level $3=$ numerous, with 5 or more flecks of dirt matter.

\section{RESULTS AND DISCUSSION}

Microbiological analysis of the minimally processed vegetables

A total of 56 samples of ready-to-use vegetables were analysed for the mesophilic and psychrotrophic microorganism counts. Analyses were carried out monthly. Mean CFU/g values for mesophilic counts ranged between $4.7 \times 10^{5}$ and $1.6 \times 10^{8} \mathrm{CFU} /$ $\mathrm{g}$ for July and March, respectively. Psychrotrophic microorganism counts ranged between $7.9 \times 10^{6}$ and $2.7 \times 10^{8}$ CFU/g for July and January, respectively. Months of higher temperatures produced higher counts; whereas lower temperature periods produced lower counts, both for mesophilic and psychrotrophic microorganisms (Fig. 1). Coliforms were analysed every two months. Out of the 28 samples studied, only one showed total coliforms less than $3 \mathrm{MPN} / \mathrm{g}$. The remaining samples produced higher counts, up to $\geq 2.4 \times 10^{4}$ MPN/g. The total coliform counts were high in all monthly samples. Mean faecal coliform counts ranged from $<3$ to $1.1 \times 10^{4}$ MPN/g. In four samples (14.3\%), coliform counts exceeded the acceptable limit; three of these were collected in January (Fig. 2), and one in March. In Brazil, the acceptable limit for faecal coliform bacteria is $10^{2} \mathrm{MPN} / \mathrm{g}$ (3). E. coli was detected in 8 samples (28.6\%). The highest counts of faecal coliforms and $E$. coli were observed in January, with a mean of $4.0 \times 10^{3} \mathrm{MPN} / \mathrm{g}$ (Fig. 2).

The mean monthly counts of mesophilic and psychrotrophic microorganisms were high in almost all months throughout the collection period. The maximum limit for aerobic mesophilic microorganisms in vegetables was established as $10^{5} \mathrm{CFU} / \mathrm{g}$ 


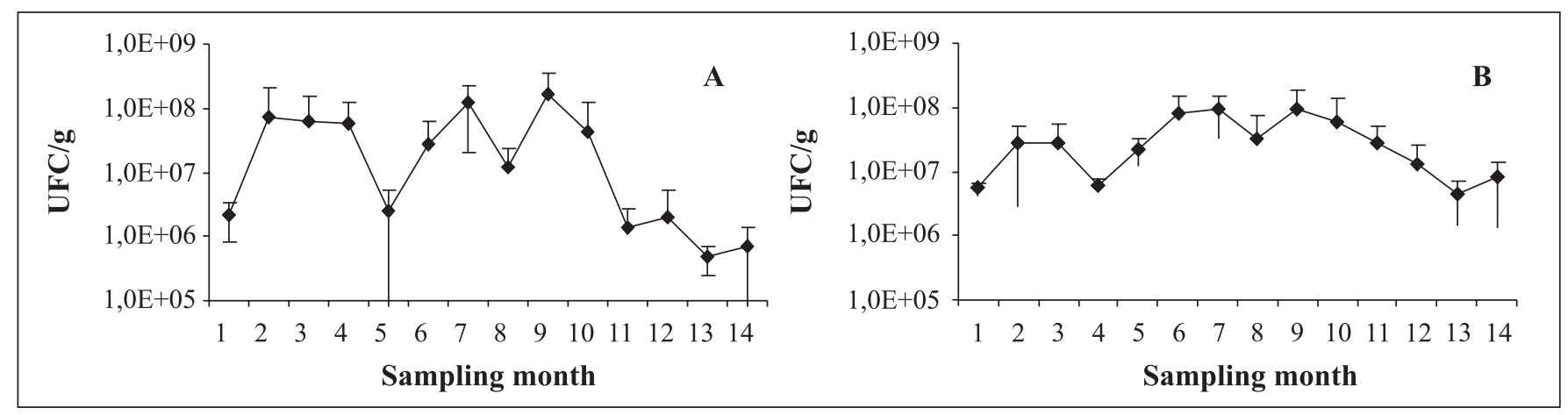

Figure 1. Mesophilic (A) and psychrotrophic (B) microorganisms in minimally processed vegetables. Points on the curves represent the mean $( \pm$ SD) microorganism counts from four monthly collections. Samples were collected from July 2004 (1) to August 2005 (14).

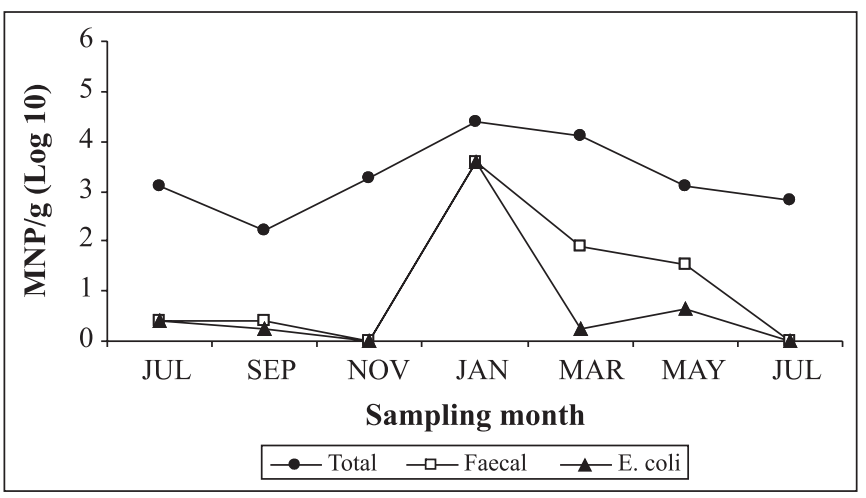

Figure 2. Levels of faecal and total coliforms and Escherichia coli expressed as MPN/g in minimally processed vegetables sold in Porto Alegre, Rio Grande do Sul, Brazil, between July 2004 and August 2005. Points on the curves represent the mean counts of four samples.

(12). The results obtained in the present study were above this limit, indicating that contamination is occurring in some stage of food processing. Even after some processing, ready-to-eat vegetables retain much of their original microbiota; this is a serious health issue, because pathogens may be part of that microbiota. Ready-to-eat vegetables must be stored under appropriate temperatures in order to inhibit the growth of these pathogens, which are generally psychrotrophic microorganisms (6). Most microorganisms found in fresh produce are psychotrophic (13), e.g., Listeria monocytogenes, which may grow in fresh produce stored under refrigeration (2). The slicing step may increase the risk of contamination: it damages the cell walls and releases cellular and vascular fluids, which become available to the microorganisms naturally present in the produce. All this processing contributes to microorganism multiplication, and eventually increases bacterial counts $(1,7)$.
Faecal coliform counts are an efficient indicator of sanitisation, although, the presence of faecal coliforms does not necessarily indicate the presence of a pathogen (13). In the present study, faecal coliform counts were high, especially in summer. The presence of $E$. coli in the samples, which were also positive for faecal coliforms, indicated faecal contamination of the ready-toeat vegetables analysed. These results are similar to those from other studies on ready-to-eat vegetables $(9,13)$ and lettuce served in restaurants (19). Bacterial counts, mainly those for psychrotrophic microorganisms, were lower in cold weather and higher in warm weather. Faecal coliforms and E. coli also showed elevated counts in January and March (austral summer).

The results obtained in the present study indicated a tendency towards higher bacterial counts in hot-season months. One of the practices that may lie behind these temperaturedependent results is the increased use of contaminated water, side by side with the heat in the natural environment, which together favour the growth of microorganisms, especially in spring and summer. Similar results for fresh vegetables have been found by other authors (17).

\section{Parasitologic and dirt matter analyses of minimally processed vegetables}

The present study detected contamination by parasites in 8 $(15.3 \%)$ of the 52 samples analysed (Fig. 3). The number of oocysts of Eimeria spp. was higher in July 2004 and July 2005. The highest relative occurrence (75\%) was observed in July 2004 and July 2005 (50\%), followed by September 2004, and April and August 2005, with 25\% positive samples. In the other months, no other parasites of human or animal origin were detected. Eimeria are protozoans that accomplish their life-cycle in animal hosts; therefore, the presence of oocysts of Eimeria spp. indicates contamination by animal faeces.

No protozoan cysts or oocysts, or helminth eggs or larvae that colonise human hosts were detected. If present, these may 
have been removed by washing and/or disinfection with chlorine (6). Coccidium oocysts are not affected by chlorine and many other chemicals used as disinfectants during these steps.

The majority of the samples analysed for the presence of dirt matter contained some of the following materials: insect body parts, young insects, young mites, aphids, and minute rock fragments. Dirt matter was detected in all the samples analysed (Fig. 4). For all months, moderate occurrence of dirt matter was observed, except for November, with $25 \%$ of samples exhibiting rare, and $75 \%$ with a moderate level of dirt matter. In March 2005, 50\% of samples contained dirt matter at the rare level, and 50\% at the high level. For July 2005, the figures were $25 \%$ and $75 \%$ for high and rare occurrence of dirt matter, respectively (Fig. 4). Such contamination is noteworthy, and is probably linked to diseases that are transmitted by drinking

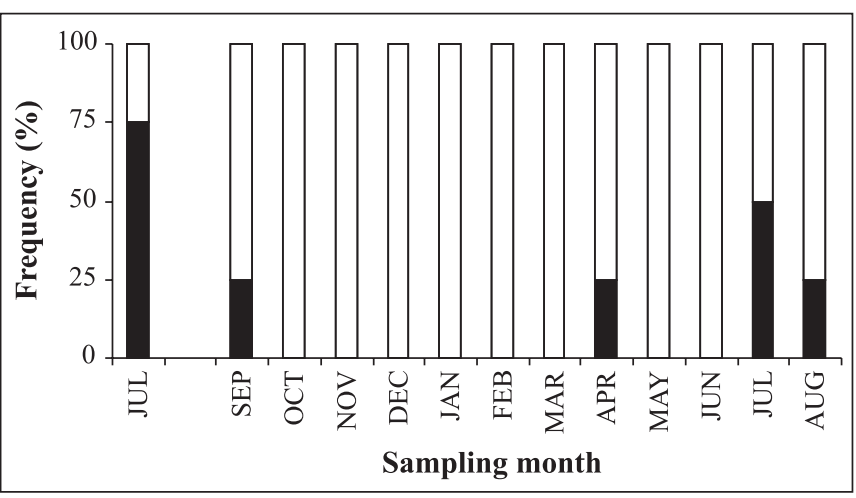

Figure 3. Incidence (\%) of Eimeria spp. in samples of minimally processed vegetables collected from July 2004 to August 2005. The presence of parasites is indicated by $(\boldsymbol{\square})$ and their absence by ( $\square$ ). No samples were collected in August 2004.

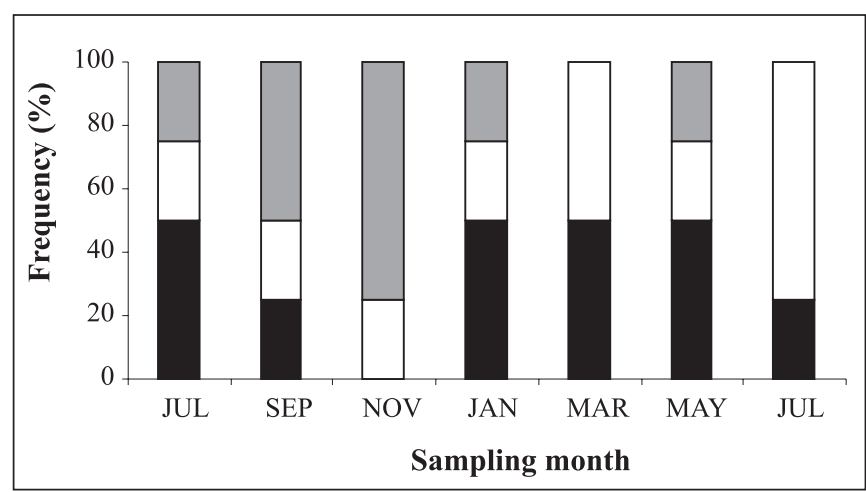

Figure 4. Occurrence of dirt matter in minimally processed vegetables sold in the city of Porto Alegre, Rio Grande do Sul, Brazil, between July 2004 and August 2005. The amount of dirt matter is shown as high $(\square)$, moderate $(\square)$ and rare ( $\square$ ). water, contact with animals, and ingestion of unwashed vegetables (14). These biological findings illustrate the value of the technique used in the present study. It is generally accepted that dirt matter may have only aesthetic significance, with no health hazards to end-users. However, dirt matter may, at times, cause health problems in humans.

The precise establishment of the origin of a disease outbreak is of crucial importance in planning the strategies and interventions to minimise future health hazards. Nevertheless, the accurate identification of primary contamination sources of fresh produce is no easy task (2). The results obtained for the bacteriological, parasitological, and dirt matter analyses for minimally processed vegetables sold in Porto Alegre, pointed to inefficiencies during sanitisation procedures in the freshproduce processing units and during storage. They also indicated an originally high bacterial load, which may have been associated with soil or irrigation water.

\section{ACKNOWLEDGEMENTS}

This study was supported by the Brazilian agency CAPES and CNPq.

\section{RESUMO}

\section{Qualidade microbiológica de hortaliças minimamente processadas comercializadas em Porto Alegre, Brasil}

Hortaliças minimamente processadas passam por várias etapas durante seu processamento, no qual ocorrem várias modificações de sua estrutura natural, todavia elas devem manter a mesma qualidade do produto não processado. $\mathrm{O}$ objetivo deste estudo foi quantificar microrganismos mesófilos e psicrótróficos, coliformes totais e fecais e verificar a presença de E. coli, parasitas e sujidades em hortaliças minimamente processadas prontas para consumo. Foram analisadas 56 amostras para mesófilos e psicrotróficos pelo método de contagem em placas, com média mensal $4,7 \times 10^{5}$ a 1,6x $10^{8} \mathrm{UFC} / \mathrm{g}$ e de $7,9 \times 10^{6}$ a $2,7 \times 10^{8} \mathrm{UFC} / \mathrm{g}$, respectivamente. Os coliformes foram analisados pela técnica dos tubos múltiplos, onde coliformes totais variaram de $<3 \mathrm{a} \geq 2,4 \times 10^{4} \mathrm{NMP} / \mathrm{g}$ e coliformes fecais, de $<3$ a $1,1 \times 10^{4} \mathrm{NMP} / \mathrm{g}$, e $E$. coli foi observada em oito amostras. De 52 amostras, $8(15,3 \%)$ apresentaram oocistos de Eimeria spp. Sujidades, como fragmentos de insetos e ácaros jovens foram encontrados. Contaminação de origem fecal foi verificada no presente estudo, sugerindo falhas nas etapas do processamento das hortaliças, ou que o solo ou a água de irrigação também poderiam ser fontes de disseminação destes microrganismos.

Palavras-chaves: hortaliças minimamente processadas, qualidade microbiológica, análise parasitológica 


\section{REFERENCES}

1. Berbari, S.A.G.; Paschoalino, J.E.; Silveira, N.F.A. (2001). Efeito do cloro na água de lavagem para desinfecção de alface minimamente processada. Cien. Tecnol. Aliment., 21: 197-201.

2. Beuchat, L.R. (1996). Pathogenic microorganisms associated with fresh produce. J. Food Prot., 59: 204-216.

3. Brasil. (2001). Ministério da Saúde. Agência Nacional de Vigilância Sanitária. Resolução: RDC No.12, 2 January 2001. Approves the Technical Regulation on microbiological standards for foodstuffs. http://www.anvisa.gov.br/.

4. Erdoğrul, Ö.; Şener, H. (2004). The contamination of various fruit and vegetable with Enterobius vermicularis, Ascaris eggs, Entamoeba histolytica cysts and Giardia cysts. Food Control, 15: 1-4.

5. Faust, E.C.; D’Antoni, J.S.; Odon, V.; Miller, M.J.; Peres, W; Sawitz, C.; Thomen, L.F.; Tobie, J.E.; Walker, J.H. (1938). A critical study of clinical laboratory technics for the diagnosis of protozoan cysts and helminth eggs in feces I. Preliminary communication. Am. J. Trop. Med. Hyg., 18: 169-183.

6. Francis, G.A.; Thomas, C.; O'Beirne, D. (1999). The microbiological safety of minimally processed vegetables. Review article. Int. J. Food Sci. Technol., 34: 1-22.

7. Gleeson, E.; O'Beirne, D. (2005). Effects of process severity on survival and growth of Escherichia coli and Listeria innocua on minimally processed vegetables. Food Control, 16: 677-685.

8. Hoffman, W.A.; Pons, J.A.; Janer, J.L. (1934). The sedimentationconcentration method in schistosomiasis mansoni. P.R. J. Public Health Trop. Med., 9: 281-298.

9. Kaneko, K.; Hayashidani, H.; Ohtomo, Y.; Kosuge, J.; Kato, M.; Takahashi, K.; Shiraki, Y.; Ogawa, M. (1999). Bacterial contamination of ready-to-eat foods and fresh products in retail shops and food factories. J. Food Prot., 62: 644-649.
10. Lin, C.M.; Fernando, S.Y.; Wei, C. (1996). Occurrence of Listeria monocytogenes, Salmonella spp., Escherichia coli and E. coli O157:H7 in vegetable salads. Food Control, 7: 135-140.

11. Michino, H.; Araki, K.; Minami, S.; Takaya, S.; Sakai, N.; Miyazaki, M.; Ono, A.; Yanagawa, H. (1999). Massive outbreak of Escherichia coli O157:H7 infection in schoolchildren in Sakai City, Japan, associated with consumption of white radish sprouts. Am. J. Epidemiol., 150: 787-796.

12. Mossel, D.A.A.; Garcia, B.M. (1982). Microbiologia de los alimentos. Zaragoza: Acribia.

13. Nguz, K.; Shindano, J.; Samapundo, S.; Huyghebaghebaert, A. (2005). Microbiological evaluation of fresh-cut organic vegetables produced in Zambia. Food Control, 16: 623-628.

14. Nimri, L.F. (2003). Cyclospora cayetanensis and other intestinal parasites associated with diarrhea in a rural area of Jordan. Int. Microbiol., 6: 131-135.

15. Oliveira, C.A.F.; Germano, P.M.L. (1992). Estudo da ocorrência de enteroparasitas em hortaliças comercializadas na região metropolitana de São Paulo, SP, Brasil. I - Pesquisa de helmintos. Rev. Saúde Pública, 26: 283-289.

16. Roever, C. De. (1998). Microbiological safety evaluations and recommendations on fresh produce. Review. Food Control, 69: 321347.

17. Ruiz, B.G.V.; Vargas, R.G.; Villanova, R.G. (1987). Contamination on fresh vegetables during cultivation and marketing. Int. J. Food Microbiol., 4: 285-291.

18. Rosa, O.O.; Carvalho, E.P. (2000). Características microbiológicas de frutos e hortaliças minimamente processados. Cienc. Tecnol. Aliment., 34: 84-92.

19. Soriano, J.M.; Rico, H.; Moltó, J.C.; Mañes, J. (2000). Assessment of the microbiological quality and wash treatments of lettuce served in University restaurants. Int. J. Food Microbiol., 58: 123-128.

20. Vanderzant, C.; Splittstoesser, D.F. (1992). Compendium of Methods for the Microbiological Examination of Foods, 3rd ed., Am. Public Health Assoc., Washington. 